\title{
Experimental investigation of the performance of a solar dryer integrated with solid desiccant coloums using water based solar collector for medicinal herb
}

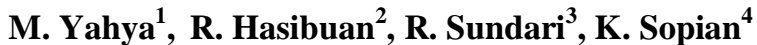 \\ ${ }^{1}$ Fakultas Teknologi Industri, Institut Teknologi Padang, Padang, Indonesia \\ ${ }^{2}$ Departemen Teknik Kimia, Universitas Sumatera Utara, Medan, Indonesia \\ ${ }^{3}$ Department of Mechanical Engineering, Universitas Mercu Buana, Jakarta, Indonesia \\ ${ }^{4}$ Solar Energy Research Institute, Universiti Kebangsaan Malaysia, Selangor, Malaysia
}

\begin{tabular}{l} 
Article Info \\
\hline Article history: \\
Received Oct 10, 2020 \\
Revised Dec 21, 2020 \\
Accepted Mar 31, 2021 \\
\hline Keywords: \\
Drying \\
Medicinal herb \\
Solar dryer \\
Solar water collector \\
Solid desiccant
\end{tabular}

Corresponding Author:

M. Yahya

Fakultas Teknologi Industri

Institut Teknologi Padang

Indonesia, 25146

Email: yahya_err@yahoo.com

\begin{abstract}
This study is concerned with the analyses of performance on a solar dryer integrated with solid desiccant coloums using water based solar collector. The dryer consists of a solar water collector, two solid desiccant coloums, a water storage tank, two heat exchangers, an air heater, and a drying chamber. The dryer decreased the Centella asiatica $L$ moisture content from $88.3 \%$ (wb) to $15.9 \%(\mathrm{wb})$ within 12 hours, with an average temperature and relative humidity of $45.4^{\circ} \mathrm{C}$ and $25.8 \%$, respectively. The rate of moisture evaporation and the specific moisture evaporation rate were in the range of $0.001-1.762 \mathrm{~kg} / \mathrm{h}$ and $0.02-0.482 \mathrm{~kg} / \mathrm{kWh}$, with $0.594 \mathrm{~kg} / \mathrm{h}$ and $0.169 \mathrm{~kg} / \mathrm{kWh}$ in average values, respectively. The dryer efficiency was in the range of $0.62 \%-30.4 \%$, with $15.4 \%$ in average value. The energy required for moisture evaporation and total energy input to the dryer were in the range of 26.9-1132.2 $\mathrm{W}$ and $3638.0-4329.7 \mathrm{~W}$, with $601.8 \mathrm{~W}$ and $3967.4 \mathrm{~W}$ in average values, respectively. The efficiency of collector and the heat exchanger effectiveness were in the range of 38.1-50.5\% and $65.1-79.7 \%$, with $45.0 \%$ and $73.0 \%$ in average values, respectively. The result shows that the dryer is suitable for drying Centella asiatica L, this is due to the low temperature of drying air and high moisture evaporation rate.
\end{abstract}

This is an open access article under the CC BY-SA license.

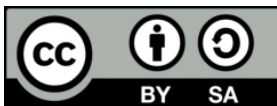

\footnotetext{
NOMENCLATURE

$\mathrm{A}_{\mathrm{C}} \quad$ Solar water collector area $\left(\mathrm{m}^{2}\right)$

$\mathrm{C}_{\mathrm{PW}_{\mathrm{W}}} \quad$ Specific heat of water $\left(\mathrm{Jkg}^{-1} \mathrm{C}^{-1}\right)$

$\mathrm{H}_{\mathrm{fg}} \quad$ Latent heat of water vaporization $(\mathrm{kJ} / \mathrm{kg})$

$\mathrm{I}_{\mathrm{T}} \quad$ solar radiation $\left(\mathrm{Wm}^{-2}\right)$

$\mathrm{M}_{\mathrm{db}, \mathrm{t}} \quad$ Moisture content at the time " $t$ " $(\mathrm{db})$

$M_{\mathrm{db}, \mathrm{t}+\Delta \mathrm{t}} \quad$ Moisture content at the time " $t+\Delta \mathrm{t}$ " (db)

$\mathrm{m}_{\mathrm{dca}} \quad$ Mass of bone dry of Centella asiatica $L(\mathrm{~kg})$

MER Rate of moisture evaporation $(\mathrm{kg} / \mathrm{h})$

$\mathrm{m}_{\text {wetca }} \quad$ Mass of wet of Centella asiatica $L(\mathrm{~kg})$

$\dot{m}_{w} \quad$ Water mass flow rate $(\mathrm{kg} / \mathrm{s})$

$\mathrm{Q}_{\text {air heater }} \quad$ Electrical energy for air heater (W)

$\mathrm{Q}_{\mathrm{B}} \quad$ Electrical power for blower $(\mathrm{W})$

$\mathrm{Q}_{\mathrm{P}} \quad$ Electrical power for water pump (W)
} 


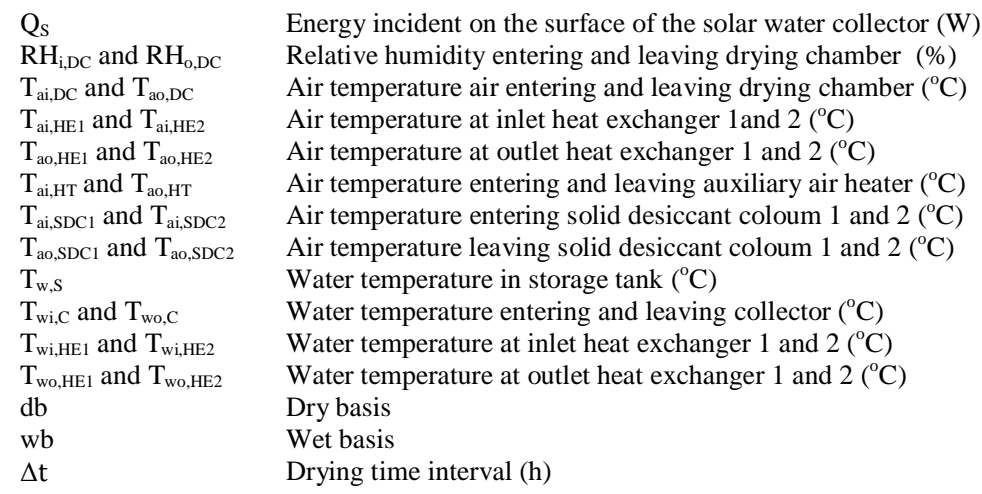

\section{INTRODUCTION}

Centella asiatica $L$ (umbelliferae) has been used as a medicinal herb since time immemorial in Indonesia, Malaysia, China, India and other parts of Asia [1]. The herb is rich in nutrients and pentacyclic triterpenes [2]. It can be used for improving memory [3], antibacterial and antifungal [4], antigenotoxic [5], antitumor [6], anti-stress [7], and antiproliferative [8].

Centella asiatica $L$ after harvested is highly perishable because it contains high moisture (80-90\% wet basis) and having a short storage life. To increase storage life the Centella asistica L must be dried. In developing countries solar dryer of hot air type is the dominant method that is used for drying medicinal herbs. Recently, various of types of medicinal herbs have been dried using the solar dryers of hor air type such as: black ginger [9], lemon verbeva leaves [10], curcuma [11], mint [12], [13], rosella [14], [15], Valeriana jatamansi [16], red pepper [17], wild ginger [18], Centella asiatica [19], thymus and mint [20], jerky [21], Andrographis paniculata [22], green tea [23], fenugreek leaves [24], and onion slice [25].

However, the moisture evaporation rate of the solar dryer of hot air type depends on the temperature of the drying air, to increase the moisture evaporation rate, it is conducted by increasing the temperature of the drying air. The high drying air temperature is not suitable for drying medicinal herb because it is heat sensitive products and results in low quality drying.

To overcome this problem, low temperature solar drying technologies must be used with high moisture evaporation rate to maintence the quality of drying products. This can be done by two methods, namely by integrating a heat pump system or a solid desiccant system into a solar dryer. In both of these methods, the moisture evaporation rate can be increased by dehumidifying of the moisture in the drying air by using an evaporator of heat pump and desiccant materials, respectively.

Several researchers have integrated and tested solar dryers with heat pump using air and water based solar collectors for drying various of types the medicinal hebrs and heat sensitive products, for using air based solar collectors such as: curcuma [26], tomato [27], banana [28], mint leaves [29], tomato, strawberry, mint, and parsley [30], agricultural food grains [31], and corn [32]. For using water based solar collectors such as: wheat [33], banana chip [34], radish [35], and mushroom [36]. However, dehumidification of the moisture in drying air can be achieved if the surface temperature of the evaporator is lower than the temperature of dew point of the drying air at inlet of the evaporator [37].

Meanwhile, several researchers have also integrated and tested solar dryers with solid desiccant bed using air based solar collector for drying various of types the medicinal hebrs and heat sensitive products such as: chili [38], green peas and pineapple slices [39], green peas [40], apricots [41], and maize [42]. And also, solar dryers integrated with desiccant wheel using water based solar collector have been tested for drying oil palm fronds and kenaf core fiber, respectively [43], [44]. The researchers found that the dryers are capable to dry the medicinal herbs and heat sensitive products because of the high moisture evaporation rate (short drying time), and high quality of the dryng product due to hot and dry air (low drying air temperature).

However, no work on experimental performance of solar dryer integrated with solid desiccant coloum using water based solar collector for drying Centella asiatica L, (medicinal herb) has been reported. Therefore, the present study aims to evaluate the performance of a solar dryer integrated with solid desiccant coloum using water based solar collector for drying Centella asiatica $L$.

\section{RESEARCH METHOD}

\subsection{Experimental set-up}

The photograph and schematic of the solar dryer integrated with solid desiccant coloums using water based solar collector as shown in Figure 1 and Figure 2. The dryer consist of a solar water collector 
(Figure 3), two water-air heat exchanger (Figure 4), two solid desiccant coloums (Figure 5), a drying chamber (Figure 6), a water storage tank (Figure 7), and an auxiliary air heater (Figure 8). The drying system has three processes, namely dehumidification, drying, and regeneration processes. The dehumidification is the process to remove the moisture from drying air using a solid desiccant, the drying is the process to remove the moisture from the Centella asiatica $L$, while the regeneration is the process to remove the moisture from the solid desiccant using hot air. The main components of the dryer specification and characteristic are presented in Table 1.

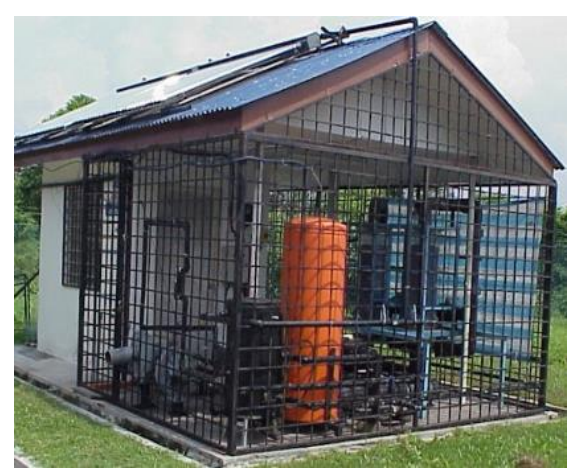

Figure 1. Photograph of the solar dryer integrated with solid desiccant coloums using water based solar collector

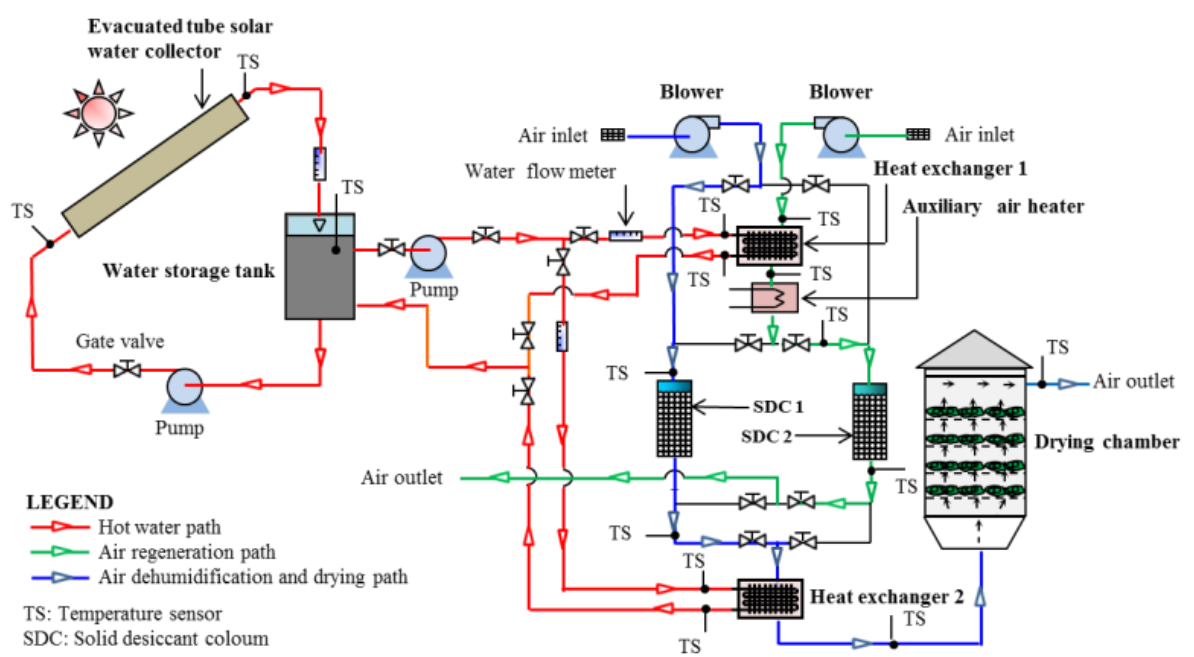

Figure 2. Schematic of the solar dryer integrated with solid desiccant coloums using water base solar collector

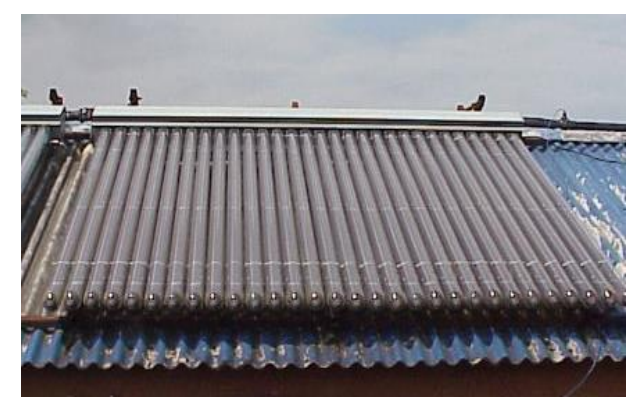

Figure 3. Photograph of the evacuated tube solar water collector

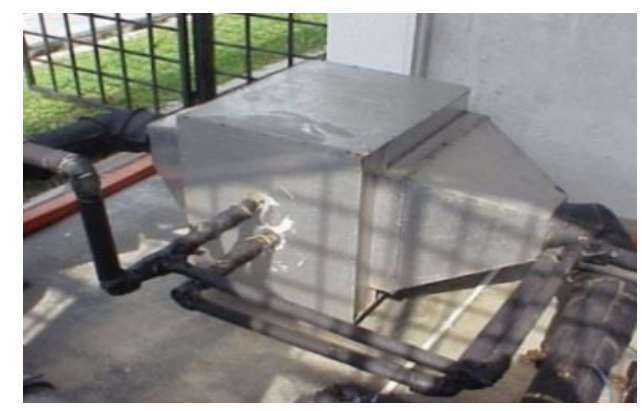

Figure 4. Photograph of the heat exchanger 


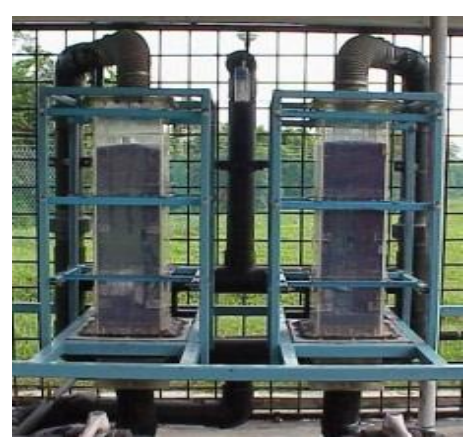

Figure 5. Photograph of the solid desiccant coloums

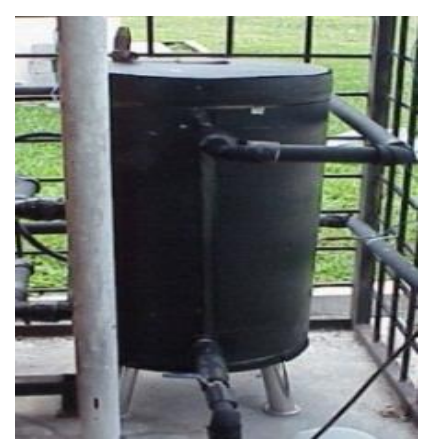

Figure 7. Photograph of the water storage tank

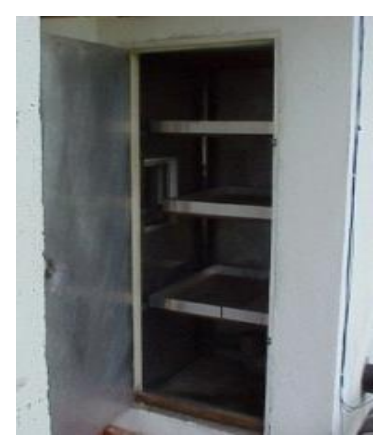

Figure 6. Photograph of the drying chamber

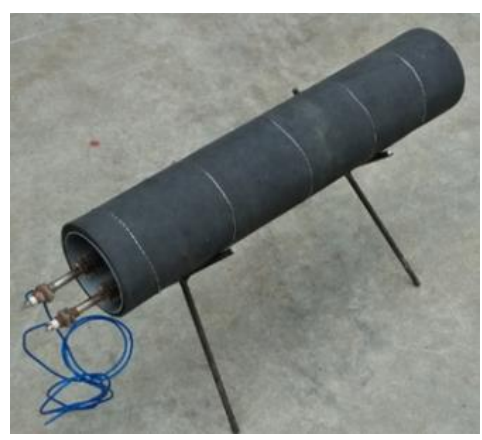

Figure 8. Photograph of the auxiliary air heater

Tabel 1. Main components specifications and characteristics of the drying system

\begin{tabular}{|c|c|c|}
\hline \multicolumn{2}{|c|}{ Component } & \multirow[t]{2}{*}{ Specification and characteristic } \\
\hline 1 & Solar water collector & \\
\hline & a. Type & Evacuated tube \\
\hline & b. Tube number & 60 \\
\hline & c. Area & $6 \mathrm{~m}^{2}$ \\
\hline & d. Manufacturer & Apricus Solar, China \\
\hline \multirow[t]{3}{*}{2} & Water storage tank & \\
\hline & a. Capacity & $80 \mathrm{~L}$ \\
\hline & b. Insulation & Glass wool and rubber foam \\
\hline \multirow[t]{4}{*}{3} & Solid desiccant columns & \\
\hline & a. Dimensions & $0.25 \mathrm{~m} \times 0.25 \mathrm{~m} \times 1 \mathrm{~m}$ \\
\hline & b. Desiccant material & Silica gel (Chemxin, China) \\
\hline & c. Coloum number & 2 \\
\hline \multirow[t]{5}{*}{4} & Drying chamber & \\
\hline & a. Type & Cabinet \\
\hline & b. Dimensions & $1 \mathrm{~m} \times 1 \mathrm{~m} \times 2.5 \mathrm{~m}$ \\
\hline & c. Tray number & 3 \\
\hline & d. Tray material & Stainless steel wire mesh \\
\hline \multirow[t]{3}{*}{5} & Heat exchanger & \\
\hline & a. Type & Cross flow plate (water-air heat exchanger) \\
\hline & b. Number & 2 \\
\hline \multirow[t]{4}{*}{6} & Auxiliary air heater & \\
\hline & a. Type & U Type stainless steel finned electric tubular \\
\hline & b. Capacity & $0.75 \mathrm{~kW}$ \\
\hline & c. Manufacturer & Superb Heater Technology, Shenzen, China \\
\hline \multirow[t]{5}{*}{7} & Blower & \\
\hline & a. Type & Centrifugal \\
\hline & b. Number & 2 \\
\hline & c. Capacity & $0.75 \mathrm{~kW}$ \\
\hline & d. Manufacturer & Xinxiang Blower Factory, China \\
\hline \multirow[t]{5}{*}{8} & Water pump & \\
\hline & a. Type & Centrifugal \\
\hline & b. Number & 2 \\
\hline & c. Capacity & $0.1 \mathrm{~kW}$ \\
\hline & d. Manufacturer & Asiatic Engineering, Japan \\
\hline
\end{tabular}




\subsection{Experimental procedure}

The drying experiment was carry out in two days, the experiment was carry out from 10:00 AM to 4:00 PM. For drying experiments, the fresh Centella asiatica $L$ is purchased from the local market. About 3 $\mathrm{kg}$ of the Centella asiatica $L$ was filled into each tray in the chamber of dryer for the experiment. The drying chamber has three trays, and the photograph of the Centella asiatica L as shown in Figure 9. The Centella asiatica $L$ was weighed every $1 \mathrm{~h}$, and temperature and solar radiation was recorded every $1 \mathrm{~h}$. Characteristic of various measurement which used in drying experiment are presented in Table 2.

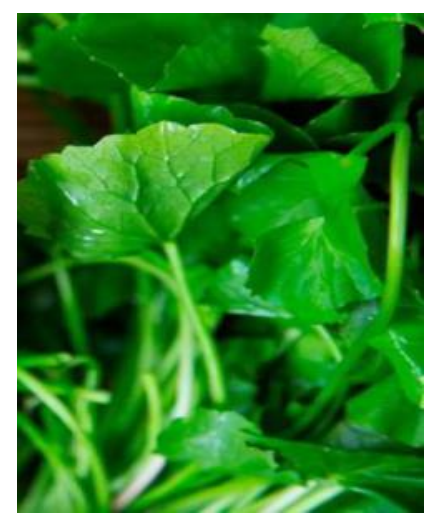

Figure 9. Photograph of the Centella asiatica $L$

Tabel 2. Characteristics of measurement of the drying system

\begin{tabular}{llll}
\hline Measuring Device & Type of measurement & Range & Accuracy \\
\hline K type thermocouple & Temperature & $-270^{\circ} \mathrm{C}$ to $1260^{\circ} \mathrm{C}$ & $2.2^{\circ} \mathrm{C}$ \\
LI-200 pyranometer & Solar radiation & $0-2000 \mathrm{Wm}^{-2}$ & $\pm 0.1 \mathrm{Wm}^{-2}$ \\
AH4000 data logger & Data transfer device & 12 channel & $\pm 0.1^{\circ} \mathrm{C}$ \\
HT-383 anemometer & Air velocity & $0-30 \mathrm{~ms}^{-1}$ & $\pm 0.1 \mathrm{~ms}^{-1}$ \\
1250A water rotameter & Water flow rate & $0.1-10 \mathrm{Lpm}$ & $\pm 5 \%$ \\
TKB-0.15 weighing & weight change & $0-15 \mathrm{~kg}$ & $\pm 0.05 \mathrm{~kg}$ \\
\hline
\end{tabular}

\subsection{Experimental data analysis}

The efficiency of collector, the effectiveness of heat exchanger, the moisture content (wb), the moisture evaporation rate (MER), the specific moisture evaporation rate (SMER), the energy required for evaporation of moisture $\left(Q_{\mathrm{ev}}\right)$, the total energy input to dryer $\left(\mathrm{Q}_{\mathrm{in}}\right)$, and the dryer efficiency were determined by using equaitions in Table 3 [21], [26], [28], [29], [35], [36], [45]. The obtained data for performance analysis during drying of Centella asiatica $L$ in two day drying experiments are presented in Table 4 on Appendix.

Tabel 3. Performance analysis

\begin{tabular}{lll}
\hline Performance indications & Performance equation & Eq.no. \\
\hline Solar water collector efficiency & $\eta_{\mathrm{coll}}=\frac{\dot{m}_{w} C_{\mathrm{Pw}}\left(T_{\mathrm{wo}, \mathrm{C}}-T_{\mathrm{wi}, \mathrm{C}}\right)}{I_{T} \mathrm{~A}_{C}} \times 100 \%$ \\
Heat exchanger effectiveness & $\varepsilon=\frac{T_{\mathrm{ao}, \mathrm{HE}}-T_{\mathrm{ai}, \mathrm{HE}}}{T_{\mathrm{wi}, \mathrm{HE}}-T_{\mathrm{ai}, \mathrm{HE}}}$ \\
Moisture content (wb) & $M_{\mathrm{wb}}=\frac{m_{\mathrm{wetca}}-\mathrm{m}_{\mathrm{dca}}}{m_{\mathrm{wwtca}}}$ \\
Rate of moisture evaporation & $\mathrm{MER}=\frac{M_{\mathrm{db}, \mathrm{t}+\Delta \mathrm{t}}-M_{\mathrm{db}, \mathrm{t}}}{\Delta \mathrm{t}}$ \\
Specific moisture evaporation rate & $\mathrm{SMER}=\frac{\mathrm{MER}}{Q_{\mathrm{in}}}$ \\
Energy required for evaporation of moisture & $Q_{\mathrm{ev}}=\mathrm{MER} H_{\mathrm{fg}}$
\end{tabular}




\section{RESULTS AND ANALYSIS}

The solar radiation, efficiency of collector, and effectiveness of heat exchanger variations with drying time are presented in Figure 10. As seen from the figure the weather is quite sunny, the solar radiation ranged between 409.0 and $930.4 \mathrm{Wm}^{-2}$, with $703.6 \mathrm{Wm}^{-2}$ in average value was recorded. The efficiency of collector ranged between 38.1 and $50.5 \%$, with average value of $45.0 \%$, at a water velocity of $0.39 \mathrm{~m} / \mathrm{s}$. The effectiveness of heat exchanger was in the range of $65.1-79.7 \%$, with average value of $73.1 \%$, at a water and an air velocity of $0.29 \mathrm{~m} / \mathrm{s}$ and $3.25 \mathrm{~m} / \mathrm{s}$, respectively. As observed from the Figure 10 the efficiency of collector is quite high, this due to the heat convective loss is low because of the high thermal resistance between absorber flat and cover glass or the internal pressure below $0.5 \mathrm{~Pa}$ (Vacuum).

The air temperature and relative humidity variations entering and leaving drying chamber versus drying time are presented in Figure 11. The air temperature entering and leaving the drying chamber were in the range of $36.8^{\circ} \mathrm{C}-49.8^{\circ} \mathrm{C}$ and $31.5^{\circ} \mathrm{C}-49.1^{\circ} \mathrm{C}$, with average values of $45.4^{\circ} \mathrm{C}$ and $38.9^{\circ} \mathrm{C}$, respectively. Whereas, the relative humidity entering and leaving the drying chamber ranged between $20.0 \%$ and $35.1 \%$, and $27.8 \%$ and $66.7 \%$, with $25.8 \%$ and $48.0 \%$ in average values, respectively. As seen from figure that the air temperature increased and relative humidity decreased leaving drying chamber with increasing in drying time. This due to, the heat and mass transfers decreased in the drying time.

The Centella asiatica $L$ moisture content and moisture evaporation rate variations versus drying time are presented in Figure 12. The Centella asiatica $L$ moisture content was reduced to $15.9 \%(\mathrm{wb})$ from $88.3 \%(\mathrm{wb})$ within 12 hours, with average air temperature of $45.4^{\circ} \mathrm{C}$ and average relative humidity of $25.8 \%$ at an air velocity of $3.25 \mathrm{~m} / \mathrm{s}$. Whereas, the moisture evaporation rate (MER) was in the range of 0.001 $1.762 \mathrm{~kg} / \mathrm{h}$, with $0.594 \mathrm{~kg} / \mathrm{h}$ in average value. Referring to Figure 12, the moisture evaporation rate decreased with increase by time, this due to the mass transfer rate decreased by time.
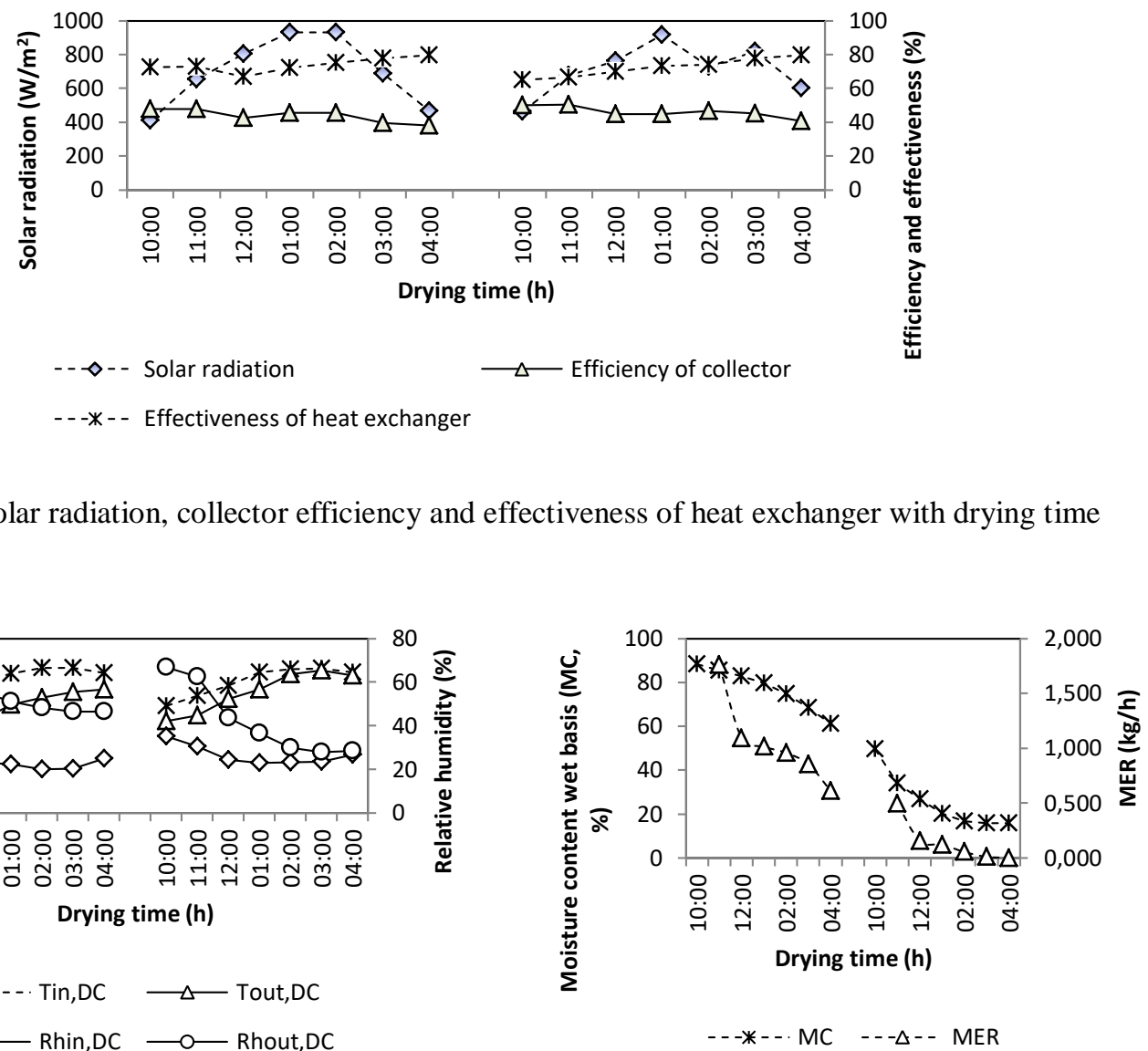

Figure 11. Temperature and relative humidity vs drying time

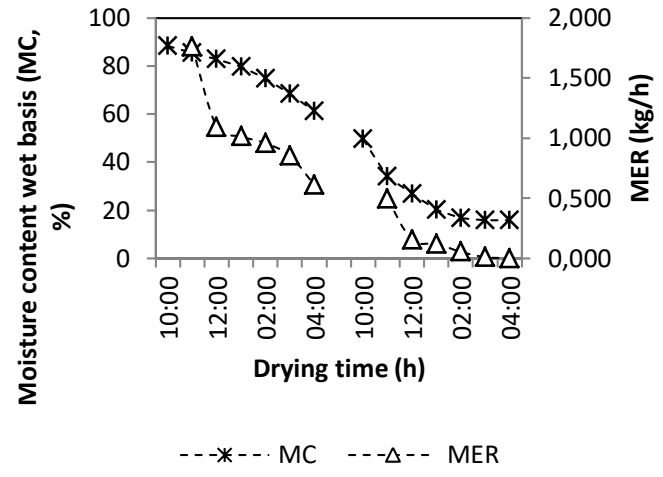

Figure 12. Moisture content and MER vs drying time 
The SMER variations versus drying time is presented in Figure 13. The SMER ranged between 0.02 and $0.482 \mathrm{~kg} / \mathrm{kWh}$, with $0.169 \mathrm{~kg} / \mathrm{kWh}$ in average value. As observed from the figure that the SMER decreased with increase by time. This due to, the rate of moisture evaporation decreased in time. The dryer efficiency, energy required for moisture evaporation, and total energy input to the dryer variations versus drying time are shown in Figure 14. The dryer efficiency ranged between $0.62 \%$ and $30.4 \%$, with average value of $15.4 \%$. Whereas, the energy required for evaporation of moisture and the total energy input to the dryer were in the range of $26.9 \mathrm{~W}-1132.2 \mathrm{~W}$ and $3638.0 \mathrm{~W}-4329.7 \mathrm{~W}$, with average values of $601.8 \mathrm{~W}$ and 3967.4 , respectively.

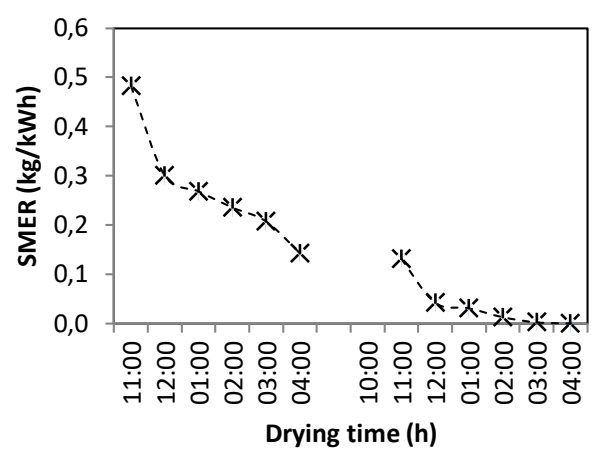

Figure 13. SMER vs drying time

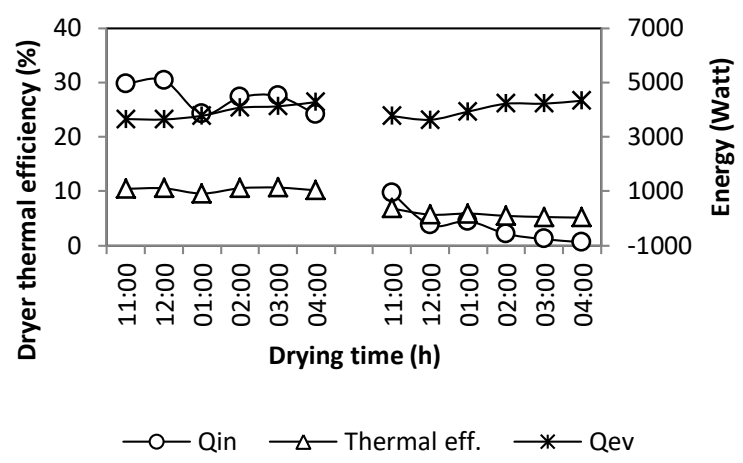

Figure 14. Dryer efficiency and energy vs drying time

\section{CONCLUSIONS}

In this study, a solar dryer integrated with solid desiccant coloums using water based solar collector was tested for drying Centella asiatica L. The results of experiment indicated that he dryer decreased the Centella asiatica $L$ moisture content from $88.3 \%$ (wb) to $15.9 \%$ (wb) in 12 hours, with average air temperature of $45.4^{\circ} \mathrm{C}$ and average relative humidity of $25.8 \%$, at $3.25 \mathrm{~m} / \mathrm{s}$ air velocity. The average of MER was $0.594 \mathrm{~kg} / \mathrm{h}$. The average of SMER was $0.169 \mathrm{~kg} / \mathrm{kWh}$. The average of dryer efficiency was $15.4 \%$. The average of energy required for evaporation of moisture was $601.8 \mathrm{~W}$. The average of total energy input to the dryer was $3967.4 \mathrm{~W}$. The average of water collector efficiency was $45.0 \%$. The average of heat exchanger effectiveness was $73.1 \%$

The result shows that the dryer is suitable for drying Centella asiatica L, this is due to the low temperature of drying air and high moisture evaporation rate.

\section{APPENDIX}

Table 4. Operating input and output parameters during dying Centella asiatica $L$.

\begin{tabular}{|c|c|c|c|c|c|c|c|c|c|c|c|c|c|c|c|c|c|c|c|}
\hline \multirow{2}{*}{$\begin{array}{l}\text { Time } \\
\text { (h) }\end{array}$} & \multirow{2}{*}{$\begin{array}{c}\text { Mass } \\
\left(M_{C A}\right) \\
(\mathrm{kg})\end{array}$} & \multirow{2}{*}{$\begin{array}{c}\text { Solar } \\
\text { radiation } \\
\left(\mathrm{W} / \mathrm{m}^{2}\right) \\
\mathrm{IT}_{\mathrm{T}}\end{array}$} & \multirow[b]{2}{*}{$\mathrm{T}_{\mathrm{w}, \mathrm{C}}$} & \multirow[b]{2}{*}{$\mathrm{T}_{\mathrm{wo}, \mathrm{c}}$} & \multirow[b]{2}{*}{$\mathrm{T}_{\mathrm{w}, \mathrm{S}}$} & \multirow[b]{2}{*}{$\mathrm{T}_{\mathrm{w}, \mathrm{HE} 1}$} & \multirow[b]{2}{*}{$\mathrm{T}_{\mathrm{wo}, \mathrm{HEI}}$} & \multirow[b]{2}{*}{$\mathrm{T}_{\mathrm{a}, \mathrm{HE} 1}$} & \multicolumn{4}{|c|}{ Temperature $\left({ }^{\circ} \mathrm{C}\right)$} & \multirow[b]{2}{*}{$\begin{array}{r}\mathrm{T}_{\mathrm{a}, \mathrm{SBCl}} \\
=\mathrm{T}_{\mathrm{a}, \mathrm{H}, \mathrm{HE} 2}\end{array}$} & \multirow[b]{2}{*}{$\mathrm{T}_{\mathrm{wi}, \mathrm{HE} 2}$} & \multirow[b]{2}{*}{$\mathrm{T}_{\mathrm{Wo}, \mathrm{HE} 2}$} & \multirow[b]{2}{*}{$\begin{array}{l}T_{\text {a } \mathrm{aHE} 2} \\
=\mathrm{T}_{\mathrm{T}, \mathrm{DC}}\end{array}$} & \multirow[b]{2}{*}{$\mathrm{T}_{\mathrm{a} 0, \mathrm{DC}}$} & \multicolumn{2}{|c|}{ Relative humidity (\%) } \\
\hline & & & & & & & & & $\begin{array}{c}\mathrm{T}_{\mathrm{a}, \mathrm{HE} 1}= \\
\mathrm{T}_{\mathrm{ai}, \mathrm{HT}}\end{array}$ & $\begin{array}{l}\mathrm{T}_{\mathrm{ao}, \mathrm{HT}}= \\
\mathrm{T}_{\mathrm{a} \mathrm{a}, \mathrm{SDC} 2}\end{array}$ & $\mathrm{~T}_{\mathrm{a} 0, \mathrm{SDC} 2}$ & $\mathrm{~T}_{\mathrm{a}, \mathrm{SDC1}}$ & & & & & & $\mathrm{RH}_{\mathrm{i}, \mathrm{DC}}$ & $\mathrm{RH}_{0, \mathrm{DC}}$ \\
\hline \multicolumn{20}{|c|}{ First day drying experiment } \\
\hline 11:00 & 7.24 & 655.60 & 42.30 & 44.60 & 44.05 & 43.62 & 42.99 & 32.50 & 40.60 & 59.80 & 38.09 & 31.40 & 40.80 & 43.78 & 42.95 & 41.16 & 29.90 & 28.40 & 62.70 \\
\hline 12:00 & 6.15 & 802.25 & 48.00 & 50.49 & 49.68 & 49.27 & 48.46 & 34.50 & 44.40 & 59.90 & 40.02 & 33.50 & 42.00 & 49.15 & 48.70 & 44.80 & 31.52 & 23.30 & 55.70 \\
\hline 1:00 & 5.13 & 929.27 & 53.00 & 56.10 & 55.13 & 54.63 & 53.56 & 35.20 & 49.20 & 59.90 & 41.10 & 34.20 & 41.70 & 55.01 & 53.66 & 48.00 & 37.35 & 22.40 & 51.20 \\
\hline 2:00 & 4.17 & 930.43 & 55.10 & 58.21 & 57.31 & 56.94 & 55.85 & 36.60 & 51.90 & 59.90 & 41.98 & 37.00 & 41.80 & 56.85 & 55.91 & 49.80 & 39.70 & 20.02 & 48.20 \\
\hline \multicolumn{20}{|c|}{ Second day drying experiment } \\
\hline 10:00 & 2.09 & 464.67 & 37.20 & 38.90 & 38.27 & 37.86 & 37.52 & 31.10 & 35.50 & 59.20 & 30.00 & 30.10 & 36.60 & 38.18 & 38.13 & 36.80 & 31.51 & 35.10 & 66.70 \\
\hline 11:00 & 1.59 & 675.98 & 41.50 & 44.00 & 43.10 & 42.82 & 42.32 & 33.50 & 39.70 & 59.80 & 39.60 & 32.70 & 39.95 & 43.03 & 42.83 & 40.40 & 33.51 & 30.60 & 62.30 \\
\hline $12: 00$ & 1.44 & 762.87 & 47.70 & 50.20 & 49.22 & 48.87 & 48.16 & 34.30 & 44.50 & 59.80 & 40.70 & 33.40 & 40.30 & 48.89 & 48.34 & 43.80 & 39.21 & 24.50 & 43.50 \\
\hline $1: 00$ & 1.32 & 917.32 & 53.50 & 56.50 & 55.53 & 54.92 & 54.04 & 36.60 & 50.00 & 59.90 & 40.90 & 34.50 & 40.30 & 55.10 & 53.46 & 48.30 & 42.40 & 23.00 & 36.60 \\
\hline 2:00 & 1.26 & 728.96 & 55.50 & 58.00 & 57.00 & 56.43 & 55.43 & 35.90 & 51.10 & 59.90 & 40.55 & 35.10 & 39.50 & 56.17 & 55.74 & 49.40 & 47.64 & 23.20 & 30.02 \\
\hline $3: 00$ & 1.25 & 820.33 & 55.50 & 58.21 & 57.30 & 56.85 & 55.85 & 36.40 & 52.30 & 59.90 & 43.10 & 35.20 & 39.40 & 56.78 & 55.00 & 49.60 & 49.05 & 23.50 & 27.88 \\
\hline 4:00 & 1.25 & 602.08 & 53.70 & 55.50 & 54.88 & 54.58 & 53.61 & 34.50 & 50.50 & 59.80 & 44.75 & 33.70 & 38.60 & 54.23 & 52.62 & 48.30 & 47.25 & 26.70 & 28.50 \\
\hline
\end{tabular}




\section{REFERENCES}

[1] P. Hashim, H. Sidek, M.H.M. Helan, A. Sabery, and U.D.P.M. Ilham, "Triterpene composition and bioactivities of Centella asiatica," Molecules, vol. 16, no. 2, pp. 1310-1322, 2011, DOI: 10.3390/molecules 16021310

[2] P.K. Inamdar, R.D. Yeole, A.B. Ghogare, and N.J. de Souza, "Determination of biologically active constituents in Centella asiatica," Journal of Chromatography A, vol. 742,no. 1-2, pp. 127-130, 1996, DOI: 10.1016/00219673(96)00237-3

[3] Y.K. Gupta, M.H. Veerendra Kumar, and A.K. Srivastava, "Effect of Centella asiatica on pentylenetetrazoleinduced kindling, cognition and oxidative stress in rats," Pharmacol. Biochem.Behav, vol. 74, no. 3, pp. 579-585, 2003, DOI: 10.1016/S0091-3057(02)01044-4

[4] M.O. Ullah, S. Sultana, A. Haque, and S. Tasmin, "Antimicrobial, cytotoxic and antioxidant of Centella asiatica," Eur. J. Sci. Res. vol.30, no. 2, pp. 260-264, 2009.

[5] Y.H. Siddique, G. Ara, T. Beg, M. Faisal, M. Ahmad, and M. Afzal, "Protective role of Centella asiatica L extract against methyl methanesulphonate and cyclophosphamide induced genotoxic damage in cultured human lymphocytes," Recent Progress in Medicinal Plants, vol. 19, Phytopharmacology and Therapeutic Values I (pp.369-381), SciTech Publishing, VA, USA.

[6] T.D. Babu, G. Kuttan, and J. Padikkala, "Cytotoxic and anti-tumor properties of ceratin taxa of Umbeliferae with special reference to Centella asiatica (L.) Urban,"J. Ethnopharmcol, vol. 48,no. 1, pp. 53-57, 1995, DOI: 10.1016/0378-8741(95)01284-k

[7] P. Puttarak, P. Dilokthornsakul, S. Saokaew, T. Dhippayom, C. Kongkaew, R. Sruamsiri, et al., "Effects of Centella asiatica (L.) Urb. on cognitive function and mood related outcomes: a systematic review and metaanalysis," Sci. Rep. vol. 7, no. 1, pp. 1-12, 2017, DOI: 10.1038/s41598-017-09823-9

[8] M. Yoshida, M. Fuchigami, T. Nago, H. Okabe, K. Matsunaga, T. Takata, et al., "Antiproliferative constituent from umbelliferae plants VII. Active triterpene and rosmarinic acid from Centella asiatica," Biology and Pharmacology Bulletin, vol. 28, no. 1, pp. 173-175, 2005, DOI: 10.1248/bpb.28.173

[9] J.P. Ekka, K. Bala, P. Muthukumar, and D.K. Kanaujiya, "Performance analysis of a forced convection mixed mode horizontal solar cabinet dryer for drying of black ginger (Kaempferia parviflora) using two successive air mass flow rates," Renewable Energy, vol. 152, pp. 55-66, 2020, DOI: 10.1016/j.renene.2020.01.035

[10] S. S. Moghaddam, M. Sharifi, and H. Zareiforoush, "Investigation of fuel consumption and essential oil content in drying process of lemon verbena leaves using a continuous flow dryer equipped with a solar pre-heating system," Journal of Cleaner Production, vol. 233, pp. 1133-1145, 2019, DOI: 10.1016/j.jclepro.2019.06.083

[11] D.V.N. Lakshmi, P. Muthukumar, J.P. Ekka, P.K. Nayak, and A. Layek, "Performance comparison of mixed mode and indirect mode parallel flow forced convection solar driers for drying Curcuma zedoaria," J. Food Process Eng. vol. 42, no. 2, pp. 1-12, 2019, DOI: 10.1111/jfpe.13045

[12] M.A. Eltawil, M.M. Azam, and A.O. Alghannam, "Energy analysis of hybrid solar tunnel dryer with PV system and solar collector for drying mint (Mentha viridis)," J. Clean. Prod. vol. 181, pp. 352-364, 2018, DOI: 10.1016/j.jclepro.2018.01.229

[13] S. Nayak, A. Kumar, J. Mishra, and G.N. Tiwari, "Drying and testing of mint (Mentha piperita) by a hybrid photovoltaic-thermal (PVT)-based greenhouse dryer," Dry. Technology, vol. 29, no. 9, pp. 1002-1009, 2011, DOI: $10.1080 / 07373937.2010 .547265$

[14] M.W. Kareem, K. Habib, M.H. Ruslan, and B.B. Saha, "Thermal performance study of a multi-pass solar air heating collector system for drying of Roselle (Hibiscus sabdariffa)," Renew. Energy, vol. 113, pp. 281-292, 2017, DOI: 10.1016/j.renene.2016.12.099

[15] S. Janjai, N. Srisittipokakun, and B. Bala, "Experimental and modeling performances of a roof integrated solar drying system for drying herbs and spices," Energy, vol. 33, no. 1, pp. 91-103, 2008, DOI: 10.1016/j.energy.2007.08.00

[16] A.K. Bhardwaj, R. Chauhan, R. Kumar, M. Sethi, and A. Rana, "Experimental investigation of an indirect solar dryer integrated with phase change material for drying Valeriana jatamansi (medicinal herb)," Case Study Therm. Eng. vol. 10, pp. 302-314, 2017, DOI: 10.1016/j.csite.2017.07.009

[17] A. Elkhadraoui, S. Kooli, I. Hamdi, and A. Farhat, "Experimental investigation and economic evaluation of a new mixed-mode solar greenhouse dryer for drying of red pepper and grape," Renew. Energy, vol. 77. pp. 1-8, 2015, DOI: 10.1016/j.renene.2014.11.090

[18] E. Aritesty, and D. Wulandani, "Performance of the rack type greenhouse solar dryer for wild ginger," Energy Proceedia, vol. 47, pp. 94-100, 2014, DOI: 10.1016/j.egypro.2014.01.201

[19] N. Srisittipokakun, and K. Kirdsiri, "Experimental performance of a mix mode solar dryer for drying Centella asiatica," Advanced Materials Research, vol. 770, pp. 80-83, 2013, DOI: 10.4028/www.scientific.net/AMR.770.80

[20] A.A. El-Sebaii, and S.M. Shalaby, "Experimental investigation of an indirect-mode forced convection solar dryer for drying thymus and mint," Energy Convers Manag., vol. 74, pp. 109-116, 2013, DOI: 10.1016/j.enconman.2013.05.006

[21] J. Banout, I. Kucerova, and S. Marek, "Using a double-pass solar dryer for jerky drying," Energy Proceedia, vol. 30, pp. 738-744, 2012, DOI: 10.1016/j.egypro.2012.11.084

[22] N. Srisittipokakun, K. Kirdsiria, and J. Kaewkhao, "Solar drying of andographic paniculata using a parabolic shaped solar tunnel dryer," Procedia Engineering, vol. 32, pp. 839-846, 2012, DOI: 10.1016/j.proeng.2012.02.021 
[23] M. Yahya, M.H. Ruslan, M.Y. Othman, B. Yatim, M.Y. Sulaiman, M. Mat, et al., "Evaluation of energy requirement for drying of green tea using a solar assisted drying system (V-groove solar collector)," In Proc. of the 3rd WSEAS Int.Conf. on Renewable Energy Sources, pp. 298-303, 2009.

[24] P.A. Potdukhe PA, and S.B. Thombre, "Development of a new type of solar dryer: its mathematical modelling and experimental evaluation," Int. J. Energy Res., vol. 32, pp. 765-782, 2008, DOI: 10.1002/er.1387

[25] P.N. Sarsavadia, "Development of a solar assisted dryer and evaluation of energy requirement for drying of onion," Renewable Energy, vol. 32, no. 15, pp. 2529-2547, 2007, DOI: 10.1016/j.renene.2006.12.019

[26] R. Hasibuan, M.Yahya, H. Fahmi, and Edison, "Comparative performance of a solar assisted heat pump dryer with a heat pump dryer for Curcuma," International Journal of Power Electronics and Drive System (IJPEDS), vol. 11, no. 3, pp. 1617-1627, 2020, DOI: 10.11591/ijpeds.v11.i3.pp1617-1627

[27] H. Atalay, "Comparative assessment of solar and heat pump dryers with regards to exergy and exergoeconomic performance," Energy, vol. 189, pp. 1-13, 2019, DOI: 10.1016/j.energy.2019.116180

[28] M. Kuan, Ye. Shakir, M. Mohanraj, Ye. Belyayev, S.Jayaraj, and A. Kaltayev, "Numerical simulation of a heat pump assisted solar dryer for continental climates," Renewable Energy, vol. 143, pp. 214-225, 2019, DOI: 10.1016/j.renene.2019.04.119

[29] I. Ceylan, and A. E. Gurel, "Solar-assisted fluidized bed dryer integrated with a heat pump for mint leaves," Applied Thermal Engineering, vol. 106, pp. 899-905, 2016, DOI: 10.1016/j.applthermaleng.2016.06.077

[30] S. Sevik, "Experimental investigation of a new design solar-heat pump dryer under the different climatic conditions and drying behavior of selected products," Solar Energy, vol. 105, pp. 190-205, 2014, DOI: 10.1016/j.solener.2014.03.037

[31] S.M.A. Rahman, R. Saidur, and M.N.A. Hawlader, "An economic optimization of evaporator and air collector area in a solar assisted heat pump drying system," Energy Conversion and Management, vol. 76, pp. 377-384, 2013, DOI: 10.1016/j.enconman.2013.06.058

[32] Y. Li, H.F. Li, Y.J. Dai, S.F. Gao, Lei Wei, Z.L. Li, et al., "Experimental investigation on a solar assisted heat pump in-store drying system," Applied Thermal Engineering, vol. 31, no. 10, pp. 1718-1724, 2011, DOI: 10.1016/j.applthermaleng.2011.02.014

[33] H. H. Ismaeel, and R. Yumrutas, "Investigation of a solar assisted heat pump wheat drying system with underground thermal energy storage tank," Solar Energy, vol. 199, pp. 538-551, 2020, DOI: 10.1016/j.solener.2020.02.022

[34] A. Singh, J. Sarkar, and R. R. Sahoo, "Experimental energy, exergy, economic and exergoeconomic analyses of batch-type solar-assisted heat pump dryer," Renewable Energy, vol. 156, pp. 1107-1116, 2020, DOI: 10.1016/j.renene.2020.04.100

[35] Y. Qiu, M. Li, R. H. E. Hassanien, Y. Wang, X. Luo, and Q. Yu, "Performance and operation mode analysis of a heat recovery and thermal storage solar-assisted heat pump drying system," Solar Energy, vol. 137, pp. 225-235, 2016, DOI: 10.1016/j.solener.2016.08.016

[36] S. Sevik, M. Aktas, H. Dogan, and S. Koçak, "Mushroom drying with solar assisted heat pump system," Energy Conversion and Management, vol. 72, pp. 171-178, 2013, DOI: 10.1016/j.enconman.2012.09.035

[37] M. Fatouh, M.N. Metwally, A.B. Helali, and M.H. Shedid, "Herbs drying using a heat pump dryer," Energy Conversion and Management, vol. 47, no. 15-16, pp. 2629-2643, 2006, DOI: 10.1016/j.enconman.2005.10.022

[38] W. Chramsa-ard, S. Jindaruksa, C. Sirisumpunwong, and S. Sonsaree, "Performance evaluation of the desiccant bed solar dryer," Energy Procedia, vol. 34, pp. 189-197, 2013, DOI: 10.1016/j.egypro.2013.06.747

[39] V. Shanmugam, and E. Natarajan, "Experimental study of regenerative desiccant integrated solar dryer with and without reflective mirror,"Applied Thermal Engineering, vol. 27, pp. 1543-1551, 2007, DOI: 10.1016/j.applthermaleng.2006.09.018.

[40] V. Shanmugam, and E. Natarajan, "Experimental investigation of forced convection and desiccant integrated solar dryer," Renewable Energy, vol. 31, no. 8, pp. 1239-1251, 2006, DOI: 10.1016/j.renene.2005.05.019

[41] R. Hodali, and J. Bougard, "Integration of a desiccant unit in crops solar drying installation: optimization by numerical simulation," Energy Conversion and Management, vol. 42, no. 13, pp. 1543-1558, 2001, DOI: 10.1016/S0196-8904(00)00159-X

[42] T. F. N. Thoruwa, J. E. Smith, A. D. Grant and C. M. Johnstone, "Developments in solar drying using forced ventilation and solar regenerated desiccant materials," Renewable Energy, vol. 9, no. 1, pp. 686-689, 1996, DOI: 10.1016/0960-1481(96)88378-9

[43] S. Misha, S. Mat, M.H. Ruslan, E. Salleh, and K. Sopian, "Performance of a solar-assisted solid desiccant dryer for oil palm fronds drying," Solar Energy, vol. 132, pp. 415-429, 2016, DOI: 10.1016/j.solener.2016.03.041

[44] S. Misha, S. Mat, M.H. Ruslan, E. Salleh, and K. Sopian, "Performance of a solar assisted solid desiccant dryer for kenaf core fiber drying under low solar radiation," Solar Energy, vol. 112, pp. 194-204, 2015, DOI: 10.1016/j.solener.2014.11.029

[45] Y.A. Cengel, and A.J. Ghajar, "Heat and mass transfer: Fundamental and applications," Fourth Edition in SI Unit, Mc. Graw-Hill, 2011. 


\section{BIOGRAPHIES OF AUTHORS}
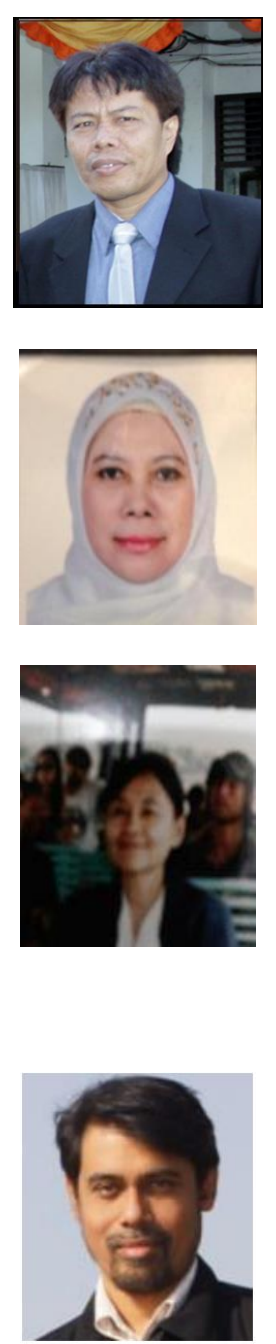

Dr. M.Yahya, MSc presently working as a Professor in Department of Mechanical Engineering, Institut Teknologi Padang, Indonesia. He recieved B.Eng degree in mechanical engineering from Universitas Bung Hatta, Padang, Indonesia, 1n 1989. He recieved M.Sc and P.hD degrees both in mechanical engineering from Universiti Kebangsaan Malaysia, in 1996 and 2007, resvectively. His research intereshs is solar thermal system (cooling and drying).

Dr. Rosdanelli Hasibuan, MT presently working as a Professor in Department of Chemical Engineering, University of Sumatera Utara, Medan, Indonesia. She recieved B.Eng degree in chemical engineering from University of Sumatera Utara, Medan, Indonesia, in 1992. She recieved M.T degree in chemical engineering from Institut Teknologi Bandung, Bandung, Indonesia, in 1998. She recieved P.hD degree in chemical engineering from Universiti Kebangsaan Malaysia, in 2005. Her research intereshs are renewable energy, drying technology and applied heat transfer.

Dr. Rita Sundari, MSc currently she is senior lecturer for numerical analysis, corrosion, polymer, industrial chemistry, and composite materials. She is working in Department of Mechanical Engineering, Universitas Mercu Buana, Jakarta, Indonesia. In recent decades, she has published several articles on chemical and biosensors, photoctalyst, corrosion engineering, and composite material fabrication, as well as herbal drying. She has given some presentations in international events held in Kuala Lumpur (Malaysia), Manila (The Philippines), Bangkok (Thailand), Khulna (Bangladesh), Shanghai (China), and Praha (Republic of Chechnya). In addition, she also wrote some book chapters related to mining relevance in environmental management, prospect and constraint in urban dynamic region, and mechanical fracture in designed alloy catalyst.

Prof Dato' Dr. Kamaruzzaman Sopian graduated with the BS Mechanical Engineering from the University of Wisconsin-Madison in 1985, the MS in Energy Resources University of Pittsburgh in 1989 and PhD in Mechanical Engineering from the Dorgan Solar Laboratory, University of Miami at Coral Gables in 1997. His research intereshs are silicon solar cell, advanced solar thermal system (cooling and drying), low energy architecture, energy management and policy studies, and renewable micropower system optimization. 